\title{
Relationship between plant species diversity and grassland condition
}

\author{
YUGUANG BAI, ZOHEIR ABOUGUENDIA, AND ROBERT E. REDMANN
}

Authors are assistant professor, Department of Plant Sciences, University of Saskatchewan, 51 Campus Drive, Saskatoon, SK S7N 5A8, Canada, manager, Grazing and Pasture Technology Program, Box 4752, Regina, SK, S4P 3Y4, Canada, and professor, Department of Plant Sciences, University of Saskatchewan, 51 Campus Drive, Saskatoon, SK S7N 5A8, Canada.

\begin{abstract}
Although the maintenance of biodiversity has become one of the goals in ecosystem management, the relationships of diversity to ecosystem characteristics such as level of herbivory, productivity, and vegetation structure are still poorly understood. We examined these relationships in 8 native grassland sites differing in grazing histories and range condition in the Mixed Grassland (6), Moist Mixed Grassland (1) and Aspen Parkland (1) ecoregions of southern Saskatchewan. Range condition, assessed using standard methods, ranged from fair to excellent. The Shannon's diversity index followed a curvi-linear relationship with range condition, increasing from fair to good, but decreasing from good to excellent condition, within a range between 0.66 and 2.58 . Species evenness was affected by range condition in a similar manner ranging from 0.44 to 0.86 . Species richness varied among sites and plots between 4 and 28 plants $0.25 \mathrm{~m}^{-2}$, but changed little with range condition. Most structural parameters, such as the cover, height, or thickness of standing plants (live or dead) and litter, increased with range condition especially from good to excellent. The Shannon's diversity index was positively correlated with forb biomass, but not with biomass of any other group or their combination. Grazing regimes that maintain good range condition also maintain species and structural diversity of grasslands.
\end{abstract}

Key Words: biomass, litter, sward structure, Saskatchewan, Canonical Correspondence Analysis (CCA), Two-way Indicator Species Analysis (TWINSPAN).

Grazing by livestock is often excluded on lands conserved for wildlife in Saskatchewan on the assumption that protection from grazing enhances habitat quality. It has been argued that the total removal of livestock is necessary to restore the health of grassland ecosystems (Fleischner 1994). On the other hand, ungulate grazing is accepted as a key process in many ecosystems, especially grasslands (West 1993), and livestock grazing has wide-

Funding was provided by the Canada-Saskatchewan Innovation Fund and the University of Saskatchewan. Pat Fargey, Daryl Nazar, Lorne Velch, and Steve McCanny helped select study sites. Thanks go to the following for allowing access to their lands: Matador, Arena, and Dixon Community Pastures; Ducks Unlimited Canada; Grasslands National Park; PFRA; and private ranchers. Thanks also are extended to Jun Zhang for assistance in data collection, Dr. V.L. Harms, PeggyAnn Ryan and Dr. J.T. Romo for their help with plant identification, and Drs. Marshall Haferkamp and John Wilmshurst for review of this manuscript.

Manuscript accepted 22 Jun. 2000.

\section{Resumen}

Aunque el mantener la biodiversidad ha venido a ser una de las metas del manejo de ecosistemas, las relaciones de diversidad con las características del ecosistema tales como el nivel de herbivoría, productividad y estructura de la vegetación aun son pobremente entendidos. Examinamos estas relaciones en 8 sitios de pastizal nativo de 3 ecoregiones diferentes del sudeste de Saskatechewan, los cuales diferían en el historial de apacentamiento y condición del pastizal, 6 sitios se ubicaron en la ecoregión de pastizal mixto, 1 en la de pastizal mixto húmedo y 1 en la del Parque Aspen. La condición de pastizal, se evaluó por métodos estándar y vario de regular a excelente. El indice de diversidad de Shannon siguió una relación curvilínea incrementando cuando la condición de pastizal paso de regular a buena y disminuyendo cuando paso de buena a excelente, dentro de un rango de 0.66 a 2.58. La uniformidad de especies fue afectada por la condición del pastizal en una manera similar variando de 0.44 a 0.86. La riqueza de especies vario entre sitios y parcelas entre 4 y 28 plantas $0.25 \mathrm{~m}^{-2}$, pero cambio poco con la condición de pastizal. La mayoría de los parámetros estructurales, tales como cobertura, altura, espesura de las plantas en pie (vivas o muertas) y el mantillo aumentaron con la condición del pastizal, especialmente cuando cambio de buena a excelente. El indice de diversidad e Shannon se correlaciono positivamente con la biomasa de hierbas, pero no con ningún otro grupo o sus combinaciones. Los regímenes de apacentamiento que mantienen una condición de pastizal buena también mantienen la diversidad de especies y estructural de los pastizales

spread influence in natural ecosystems of western North America (Wagner 1978, Crumpacker 1984). Some research indicates that moderately grazed lands can actually be healthier, produce more forage and have less standing dead materials than rangelands where grazing is excluded (G.E. Shuman, Stelljes and Senft 1994, Howitt 1995). Rangelands in good ecological condition support more wildlife than those in excellent condition due to the lack of diversity in plant species and structure in the latter (Smith et al. 1996). Diverse plant communities can be more resistant to disturbances (McNaughton 1985, Tilman and Downing 1994).

The structure, functioning, and species diversity of grassland ecosystems are inter-related (Archer and Smeins 1991, Tilman and Downing 1994) and can be altered by grazing (Huntly 1991). Improper utilization of rangelands by over-grazing can reduce cover and diversity of native plant species (Brady et al. 1989, Cooperrider 1991). Although theoretical models predict that 
moderate grazing may enhance species diversity compared to ungrazed lands (Milchunas et al. 1988), factors influencing biodiversity are still incompletely understood (West 1993, Olff and Ritchie 1998). Experimental data from a wide range of environmental conditions are needed to predict how grazing affects biodiversity in grassland ecosystems. We studied 8 grassland sites across southern Saskatchewan with the objectives: (1) to compare plant species diversity and productivity of ungrazed grasslands with those under light, moderate or heavy grazing, and (2) to evaluate the relationships among plant species diversity, range condition, biomass and sward structure.

\section{Materials and Methods}

\section{Site selection}

Eight sites in southern Saskatchewan were selected in June 1997 based on their geographical locations, soil characteristics, and grazing regimes (Table 1). One site was located in the Aspen Parkland Ecoregion, 1 in the Moist Mixed Grassland Ecoregion, and the remaining 6 in the Mixed Grassland Ecoregion. All sites were located in the Brown Soil Zone except Estevan which was in the Dark Brown Soil Zone. The soils in both zones are chernozemic. At each site, an ungrazed sub-site was located inside a fenced exclosure; these sub-sites had been protected from domestic grazing from 5 to over 30 years prior to this study. Adjacent sub-sites under light, moderate, and/or heavy grazing also were selected. Estimates of grazing intensity were based on visual inspection and information provided by range managers and ranchers, and were relative to adjacent protected sub-sites. All plots were located on level upland to avoid variations caused by slope and/or aspect. A $1 \mathrm{x}$ $1 \mathrm{~m}$ exclosure cage was placed near each plot in the grazed sub-sites to permit measurement of biomass.

\section{Field sampling and data collection}

Field sampling was conducted in July and August 1997. Four, 8 x 8 m plots were randomly selected in both protected and grazed sub-sites within the most common plant community at each site. Eight, $0.5 \mathrm{x}$ $0.5 \mathrm{~m}$ quadrats were randomly placed in each plot. The percent cover and percent contribution to total shoot biomass of each vascular species were visually estimated. Species in the genus Carex were pooled as Carex sp. except for low sedge (C. stenophylla Wahl ssp. eleocharis (Bailey) Hulten).

The percent biomass of each species was used to calculate range condition scores ( 0 to $100 \%)$, based on the contribution of climax species to total yield fol- lowing procedures in Abouguendia (1990). Range condition scores were divided into 4 classes: poor (0 to $24.9 \%$ ), fair (25 to $49.9 \%$ ), good (50 to $74.9 \%$ ), and excellent (75 to $100 \%$ ). Each class was further divided into 3 equal sub-classes, for example, excellent (-), excellent, and excellent $(+)$.

The percent cover of litter, live clubmoss (Selaginella densa Rydb.), dead clubmoss, and bare soil surface within each quadrat were visually estimated. The height of live vegetation and standing dead materials, and thickness of the litter layer also were measured with a ruler. Forbs, grasses, and standing dead materials were clipped and litter was hand-raked from $1 \times 1 \mathrm{~m}$ quadrats in each plot and put in separate paper bags. Litter was defined as any dead plant materials lying on the soil surface. Harvested materials were oven-dried at $80^{\circ} \mathrm{C}$ for 48 hours and weighed to give biomass.

\section{Data analysis}

Mean percent cover of each species was calculated for each plot. Species richness, evenness, and Shannon Diversity Index for each plot were calculated using PCORD (McCune and Mefford 1995). Data on species richness, evenness, diversity index, biomass, and structural parameters were analysed for each site to detect the effect of grazing treatment using a one-

Table 1. Descriptions of 8 grassland sites in southern Saskatchewan.

\begin{tabular}{|c|c|c|c|c|}
\hline Site/sub-site & Location & Township & Ecoregion $^{1}$ & Utilization \\
\hline $\begin{array}{l}\text { Grasslands National Park } \\
\mathrm{NG}^{2} \\
\mathrm{MG}\end{array}$ & $\mathrm{N} 49^{\circ} 10^{\prime} \mathrm{W} 107^{\circ} 30^{\prime}$ & Tp2R10W3 & Mixed grassland & $\begin{array}{l}\text { Protected for about } 5 \text { years } \\
\text { Summer grazing (Jun.-Sep.) }\end{array}$ \\
\hline Matador & $\mathrm{N} 50^{\circ} 30^{\prime} \mathrm{W} 107^{\circ} 30^{\prime}$ & Tp20R13W3 & Mixed grassland & \\
\hline $\begin{array}{l}\text { NG } \\
\text { LG }\end{array}$ & & & & $\begin{array}{l}\text { Protected for over } 30 \text { years } \\
\text { No or light grazing (Jul.-Sep.) in the last } 3 \text { years }\end{array}$ \\
\hline Parkbeg & $\mathrm{N} 50^{\circ} 20^{\prime} \mathrm{W} 106^{\circ} 10^{\prime}$ & Tp18R3W3 & Mixed grassland & \\
\hline $\begin{array}{l}\mathrm{NG} \\
\mathrm{HG}\end{array}$ & & & 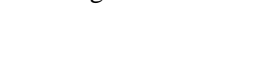 & $\begin{array}{l}\text { Protected for } 7 \text { years } \\
\text { Summer grazing (Jun.-Aug.) }\end{array}$ \\
\hline Arena & $\mathrm{N} 49^{\circ} 20^{\prime} \mathrm{W} 109^{\circ} 05^{\prime}$ & Tp5R23W3 & Mixed grassland & \\
\hline $\begin{array}{l}\text { NG } \\
\text { MG }\end{array}$ & & & & $\begin{array}{l}\text { Protected for } 6 \text { years } \\
\text { Late summer grazing (Aug.-Sep.) }\end{array}$ \\
\hline Chaplin & $\mathrm{N} 50^{\circ} 30^{\prime} \mathrm{W} 106^{\circ} 40^{\prime}$ & Tp17R4W3 & Mixed grassland & \\
\hline $\begin{array}{l}\mathrm{NG} \\
\mathrm{HG}\end{array}$ & & & 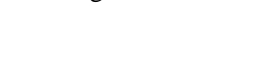 & $\begin{array}{l}\text { Protected for } 15 \text { years } \\
\text { Late summer grazing (Aug.-Sep.) }\end{array}$ \\
\hline Kerr & $\mathrm{N} 49^{\circ} 55^{\prime} \mathrm{W} 105^{\circ} 40^{\prime}$ & Tp14R28W2 & Mixed grassland & \\
\hline $\begin{array}{l}\mathrm{NG} \\
\mathrm{HG}\end{array}$ & & & & $\begin{array}{l}\text { Protected for } 7 \text { years } \\
\text { Late summer grazing (Aug.-Sep.) }\end{array}$ \\
\hline Estevan & $\mathrm{N} 49^{\circ} 05^{\prime} \mathrm{W} 103^{\circ} 05^{\prime}$ & Tp2R5W3 & Moist mixed grassland & \\
\hline $\begin{array}{l}\text { NG } \\
\text { LG }\end{array}$ & & & & $\begin{array}{l}\text { Protected for over } 10 \text { years } \\
\text { Summer grazing (Jul.-Sep.) }\end{array}$ \\
\hline $\begin{array}{l}\text { Glenavon } \\
\text { NG } \\
\text { MG } \\
\text { HG }\end{array}$ & $\mathrm{N} 50^{\circ} 0^{\prime} \mathrm{W} 103^{\circ} 00^{\prime}$ & Tp13R8W3 & Aspen parkland & $\begin{array}{l}\text { Protected for } 6 \text { years } \\
\text { Late summer grazing(Jul.-Sep.) } \\
\text { Late summer grazing (Jul.-Sep.) }\end{array}$ \\
\hline
\end{tabular}

${ }^{\mathrm{T}}$ Based on Padbury and Action 1994.

${ }^{2} \mathrm{NG}$ : no grazing, LG: light grazing, MG: moderate grazing, HG: heavy grazing. 
way ANOVA; means were separated with LSD (Snedecor and Cochran 1980). Regression analysis was used to compare range condition score with species diversity, biomass and structural parameters, and to compare the Shannon's diversity index with biomass.

Mean cover was used in multivariate analysis with each plot being treated as an individual unit. Species occurring in less than $5 \%$ of the plots were eliminated and data were relativized by the overall maximum value before TWINSPAN (Two-way Indicator Species Analysis) for the classification of sites and sub-sites using PCORD (McCune and Mefford 1995). Cut levels of $0.00,0.02,0.05,0.10$, and 0.20 were used and TWINSPAN terminated at a level with 3 or fewer plots in a group. The mean range condition score of each TWINSPAN group was calculated and the group was named by the most representative sub-site(s). Parameters such as percent cover of live vegetation, litter, live clubmoss, dead clubmoss and bare soil, the height of live vegetation and standing dead materials, the thickness of litter, the biomass of forbs, grass, standing dead materials and litter, as well as range condition score were treated as environmental variables in Canonical Correspondence Analysis (CCA). Both species percent cover and environmental variables were relativized by species or environmental variable maximum, respectively, before CCA. Axis scores were centered and standardized to unit variance and were scaled to optimize the representation of plots (weighted mean scores for species cover). The scores for environmental variables were multiplied by 2 for easy visualization. A joint plot was generated based on the linear combinations of environmental variables and the intraset correlations for environmental variables of Ter Braak (1986).

\section{Results and Discussion}

\section{Range condition and species compo- sition as affected by grazing}

Range condition in the 17 sub-sites ranged from fair to excellent (+) (Table 2). Range condition scores were significantly reduced by grazing at 3 of the 8 sites. As range condition changed from excellent $(+)$ to good at Chaplin, needle-and-thread (Stipa comata Trin. \& Rupr.) remained relatively unchanged, but western porcupine grass ( $S$. curtiseta Hitchc.) cover was reduced 7-fold and june grass (Koeleria gracilis Pers.) cover increased from 7 to 11\%. Northern wheatgrass (Agropyron dasystachyum (Hook.) Scribn.) was reduced in cover at Kerr when range condition changed from good to fair, while the cover of moss phlox (Phlox hoodii Richardson) and june grass increased. As grazing pressure increased, plains rough fescue (Festuca hallii (Vasey) Piper) decreased at Glenavon in the Aspen Parkland Ecoregion. Kentucky blue grass (Poa pratensis L.) increased in cover when range condition was reduced from excellent (-) to good (-), but decreased at fair (+) when western wheatgrass (Agropyron smithii Rydb.) became dominant.

Even for sites that did not differ significantly in range condition between grazed and ungrazed sub-sites, species composition tended to be modified by grazing (Table 2). The common decreasers included northern wheatgrass, winterfat (Eurotia lantata (Pursh) Moq.) and sand grass (Calamovilfa longifolia (Hook.) Scribn.), while june grass, western wheat grass, and Kentuchy blue grass were among increasers. Ungrazed sub-sites at Parkbeg and Kerr were not in the highest range condition category, probably because the short protection period was insufficient for full recovery from previous grazing. Some severely disturbed Northern Mixed Prairie sites require decades to reach excellent condition through natural succession (J.F. Dormaar, personal communication).

Table 2. Dominant species (with percent cover in parentheses) and range condition at 8 grassland sites in southern Saskatchewan. Values are means $\pm S E$ of 4 replicates.

\begin{tabular}{|c|c|c|c|}
\hline Site/sub-site & Dominant species $^{1}$ & Range condition & Range condition \\
\hline \multicolumn{4}{|c|}{ Grasslands National Park } \\
\hline $\mathrm{NG}^{2}$ & NWG (29), JNG (11), NAT (10) & excellent & $81 \pm 3$ \\
\hline MG & NWG (13), NAT (7), JNG (5) & excellent (-) & $79 \pm 2$ \\
\hline \multicolumn{4}{|l|}{ Matador } \\
\hline NG & NWG (41), JNG (13), WFT (8) & excellent $(+)$ & $94 \pm 3$ \\
\hline LG & NWG (28), JNG (19), WWG (3) & excellent & $88 \pm 2$ \\
\hline \multicolumn{4}{|l|}{ Parkbeg } \\
\hline NG & NAT (37), NWG (17), JNG (10) & $\operatorname{good}(-)$ & $52 \pm 13$ \\
\hline HG & NAT (29), JNG (13), NWG (8) & $\operatorname{good}(-)$ & $50 \pm 5$ \\
\hline \multicolumn{4}{|c|}{ (2) } \\
\hline NG & NWG (24), NAT (13), PAS (13) & excellent (-) & $76 \pm 9$ \\
\hline MG & NWG (15), NAT (10), WPG (9) & $\operatorname{good}(+)$ & $71 \pm 5$ \\
\hline \multicolumn{4}{|c|}{ (2) } \\
\hline NG & WPG (43), NAT (7), NWG (5) & excellent $(+)$ & $92 \pm 3^{*}$ \\
\hline HG & JNG (11), NAT (8), WPG (6) & good & $64 \pm 6$ \\
\hline \multicolumn{4}{|c|}{ (2) } \\
\hline NG & NWG (26), PAS (14), BGR (8) & good & $66 \pm 3^{*}$ \\
\hline $\mathrm{HG}$ & PHX (14), PAS (12), JNG (8) & fair & $41 \pm 3$ \\
\hline \multicolumn{4}{|l|}{ Estevan } \\
\hline NG & SAG (18), WPG (18), SED (9) & excellent (-) & $78 \pm 7$ \\
\hline LG & WPG (20), KBG (18), NWG (10) & good & $67 \pm 17$ \\
\hline \multicolumn{4}{|c|}{ (2) } \\
\hline NG & PRF (49), KBG (6), WPG (6) & excellent (-) & $81 \pm 6^{*^{3}}$ \\
\hline MG & KBG (30), PRF (11), WPG (7) & $\operatorname{good}(-)$ & $53 \pm 5$ \\
\hline HG & WWG (13), KBG (9), WPG (8) & fair $(+)$ & $43 \pm 5$ \\
\hline
\end{tabular}

BGR, Bouteloua gracilis; JNG, Koeleria gracilis; KBG, Poa pratensis; NAT, Stipa comata; NWG, Agropyron dasystachyum; PAS, Artemisia frigida; PHX, Phlox hoodii; PRF, Festuca hallii; SAG, Calamovilfa longifolia; SED, Carex sp.; WFT, Eurotia lanata; WPG, Stipa curtiseta; WWG, A. smithii.

${ }^{2} \mathrm{NG}$ : no grazing, LG: light grazing, MG: moderate grazing, HG: heavy grazing.
Plots in the 17 sub-sites were classified into 11 groups of 6 levels by TWINSPAN, based on species composition and cover (Fig. 1). Both species composition and range condition were reflected in the TWINSPAN output. Generally, the geographic location or ecoregion of a site was more important than grazing treatment in determining plant species composition.

Glenavon and Estevan were separated rom the rest of the sites by their high ef Kentucky blue grass, purple (Astragalus danicus Retz.) and cover of low sedge and june grass. Glenavon was separated from Estevan by its higher cover of plains rough fescue and reen needle grass (Stipa viridula Trin.), the black soil zone, and lower cover of sand grass and dotted blazingstar Liatris punctata Hook.). Heavily grazed navon sub-sites had less plains rough ededed and increased after heavy grazing. Matador differed from Parkbeg, Chaplin, Arena and Kerr by its high cover of yarrow (Achillea millefolium L.). Species composition and lightly grazed plots at Matador (even northern wheatgrass decrease after grazing as shown in Table 2). 


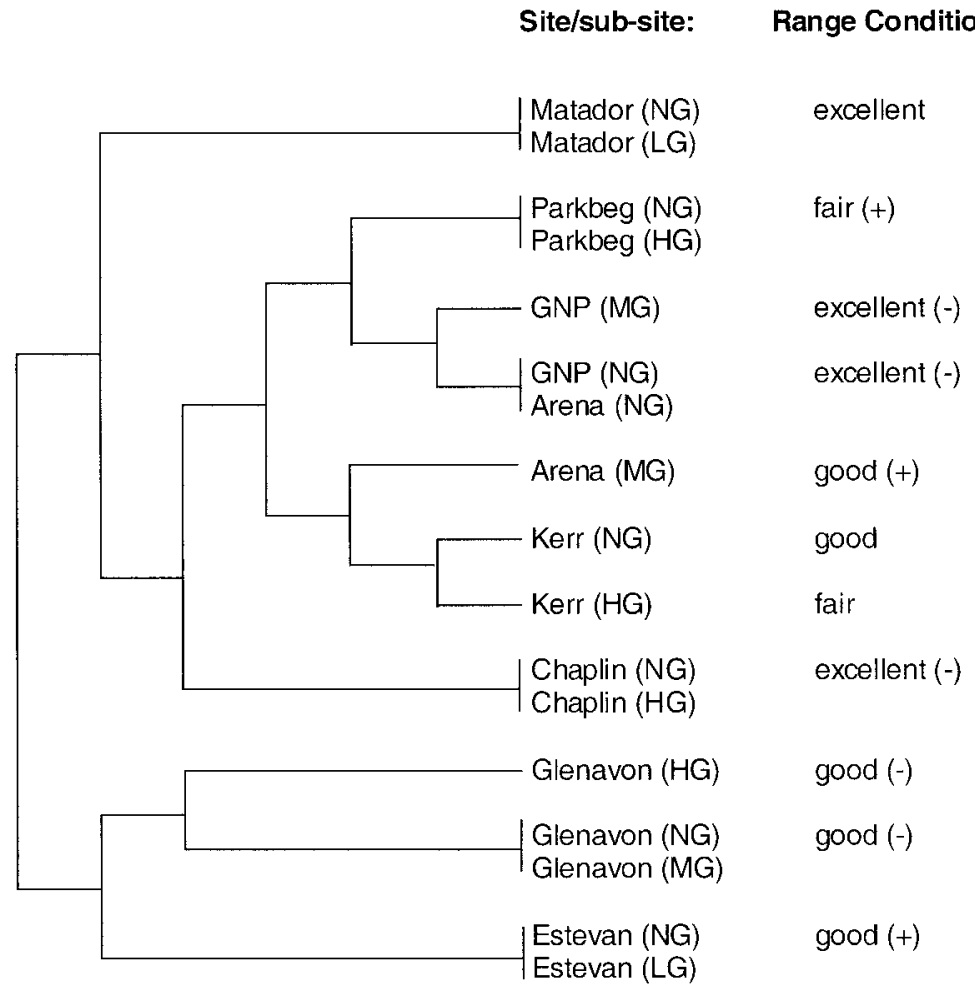

Fig. 1. Classification of grassland sites in southern Saskatchewan based on TWINSPAN and the range condition score for each group. NG: no grazing, LG: light grazing, MG: moderate grazing, HG: heavy grazing, GNP: Grassland National Park.

Chaplin had lower cover of crocus anemone (Anemone patens L. var. wolfgangiana (bess.) Koch), western porcupine grass, sedges (other than low sedge), and Hooker's oat grass (Helictotrichon hookeri (Scribn.) Henr.), but higher june grass, than Parkbeg, Grasslands National Park (GNP), Arena and Kerr.

Parkbeg, GNP and ungrazed Arena subsites had higher cover of prairie muhly (Muhlenbergia cuspidada (Torr.) Rydb.) and lower moss phlox than Kerr and moderately grazed Arena sub-sites. Parkbeg was separated from GNP and ungrazed Arena sub-sites by its higher cover of june grass and lower cover of pasture sage (Artemisia frigida Willd.), northern wheatgrass and moss phlox. There was no difference in species composition for grazed and ungrazed Parkbeg sub-sites; both had low range condition scores. The moderately grazed Arena sub-sites had higher cover of northern wheatgrass and lower sedges (other than low sedge), and spiny ironplant (Haplopappus spinulosus (Pursh) DC). Moderately grazed sub-sites at GNP had less cover of white prairie aster (Aster falcatus Lindl.) than ungrazed GNP and Arena sub-sites (Fig. 1). Ungrazed Kerr sub-sites had less skeletonweed (Lygodesmia juncea (Pursh) D.
Don), but higher northern wheatgrass; moss phlox became dominant after heavy grazing.

\section{Relationships between plant species diversity and range condition} sity index was 1.69 and 1.95 for ungrazed and grazed sub-sites, respectively. The range of this index was between 0.66 and 2.58 among plots, or between 1.23 and 2.17 among sub-sites. Shannon's diversity index was statistically higher in grazed compared to ungrazed sub-sites at Grasslands National Park (GNP) (2.12 and 1.75, respectively) and Chaplin (2.09 and 1.50 , respectively). For other sites, light grazing had little effect on species diversity; the effect of moderate and heavy grazing tended to depend on the difference in range condition between ungrazed and grazed sub-sites. The relationship between Shannon's diversity index and range condition was best described by a quadratic dition had the highest index. Decreases toward both fair and excellent conditions tend to confirm trends predicted by theoretical models (Milchunas et al. 1988).

The relationship between species evenness and range condition also followed a
The overall average of Shannon's diverequation (Fig. 2). Plots in good range con- quadratic equation (Fig. 2). Species evenness for plots in good condition decreased toward both fair and excellent conditions, within a range between 0.56 and 0.78 among sub-sites, or between 0.44 and 0.86 among plots. Grazed sub-sites had slightly higher evenness (0.75) than ungrazed ones (0.65). Grazing did not affect species evenness at individual sites except for Chaplin, where heavy grazing enhanced evenness ( 0.76 vs 0.56 ).

The effect of grazing on species richness was not significant at any site, averaging 14 and 16 for ungrazed and grazed subsites, respectively. However, species richness varied among sub-sites. The highest species richness was found in moderately grazed Glenavon sub-site (20.8) while the lowest in ungrazed Parkbeg sub-site (7.8). No clear relationship between species richness and range condition was found (Fig. 2). The total number of species, or species richness, did not necessarily reflect shifts in species composition. In other words, even though species compo-

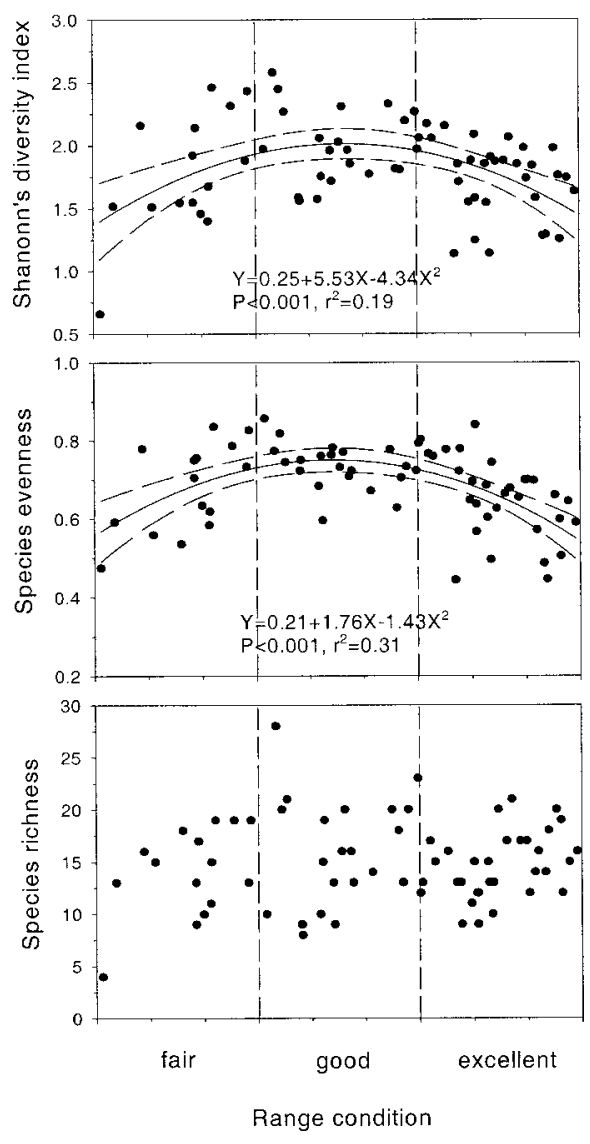

Fig. 2. The Shannon's diversity index, species evenness and richness in relation to range condition of grassland sites in southern Saskatchewan. Data of all plots were pooled. Lines represent regressions and $95 \%$ confidence intervals. 


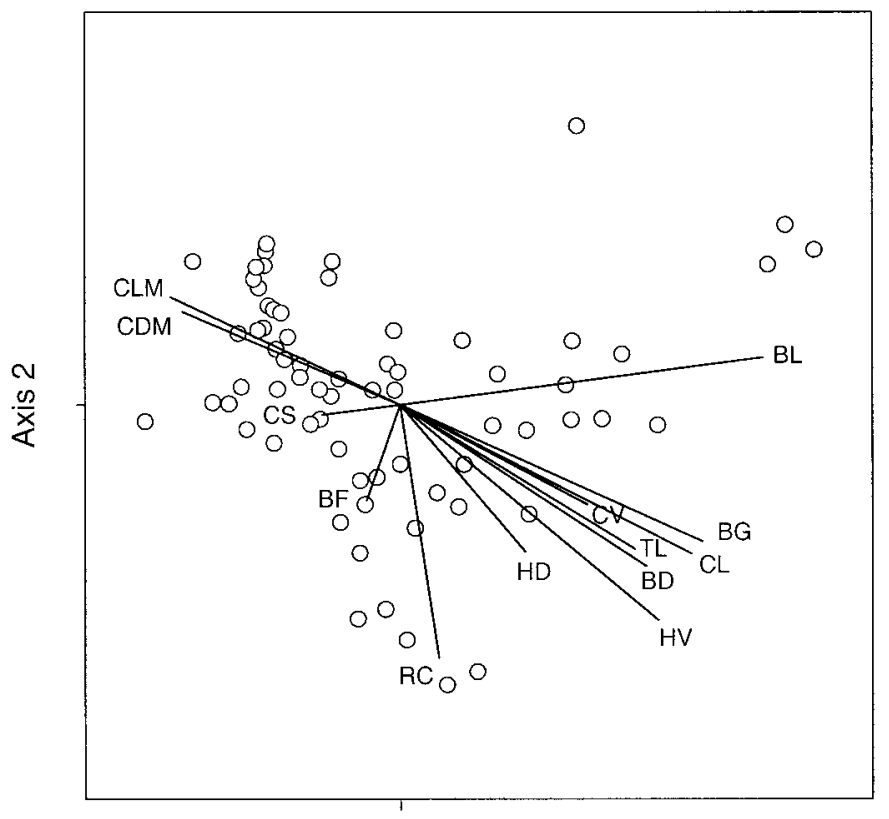

Axis 1

Fig. 3. Joint plot of Canonical Correspondence Analysis (CCA) of grasslands in southern Saskatchewan. Pooled data for all plots. CV: cover of live vegetation, CL: cover of litter, CLM: cover of live clubmoss, CDM: cover of dead clubmoss, CS: cover of bare soil, HV: height of live vegetation, HD: height of standing dead materials, TL: thickness of litter cover, BG: biomass of grass, BF: biomass of forb, BD: biomass of standing dead materials, BL: biomass of litter, RC: range condition score. in the effect of grazing on plant species diversity among sites found in the current study are not surprising because those sites were spread over 3 ecoregions. Species diversity is more likely to be reduced by grazing in stressful environments, such as dry or saline conditions (Milchunas et al. 1988, Olff and Richie 1998), or on poor soils (Ritchie and Olff 1998).

\section{Effect of grazing on sward structure}

Heavy grazing reduced the biomass of grasses (Glenavon, Chaplin and Kerr), and favoured that of forbs (Kerr) (Table 3), a trend reported elsewhere (Ten Harkel and Van der Meulen 1996, Watt et al. 1996). Moderate grazing reduced (GNP), or had no influence on grass biomass (Glenavon and Arena); its effect on forbs was not significant at these sites. Light grazing did not affect grass biomass, but reduced forbs in at least 1 site (Matador).

The biomass of standing dead materials and litter also tended to be reduced by grazing (Table 3 ). Standing dead materials showed a weak, but positive, linear relationship with range condition $(\mathrm{Y}=2.1+$ $\left.55.9 \mathrm{X}, \mathrm{P}=0.026, \mathrm{r}^{2}=0.06\right)$, while the relationship between range condition and the biomass of forb, grasses, or litter was less apparent. The biomass of forb exhibited a positive relationship with the sition differs between grazed and ungrazed grasslands, species richness may be similar, as reported in previous studies (Kelt and Valone 1995).

A higher species richness and diversity of grazed plots compared to ungrazed has been reported for tallgrass prairie (Collins 1987, Hartnett et al. 1996), and African grasslands (Smart et al. 1985). High diversity is usually attributed to greater microsite diversity generated by grazing. Other empirical studies have also demonstrated higher species diversity in moderately disturbed than in stable plant communities (Sousa 1980). Plant species diversity can be enhanced by direct consumption of dominant species and indirect effect on competition (McNaughton 1985, Milchunas et al. 1988, Szaro 1989, Huntly 1991, Olff and Ritchie 1998). Savory (1988) suggests that intensive time-controlled, short-duration, planned-rotation grazing will shift rangeland vegetation to more successionally advanced and desirable species. However, this enhanced effect may disappear after heavy grazing due to the shift of species composition to a few dominant species (Davidson 1993, Anderson and Briske 1995). In many rangelands the cumulative effect of longterm grazing is to keep succession in early stages (Longhurst et al. 1982). Variations
Table 3. Biomass of grass, forb, standing dead materials and litter at 8 sites in southern Saskatchewan. Values are means \pm SE of 4 replicates.

\begin{tabular}{|c|c|c|c|c|}
\hline Site/sub-site & Grass & Forb & Standing dead & Litter \\
\hline \multicolumn{5}{|c|}{ Grasslands National Park } \\
\hline $\mathrm{NG}^{1}$ & $60.9 \pm 2.7 * 2$ & $29.6 \pm 5.9$ & $17.4 \pm 1.2 *$ & $27.4 \pm 1.2$ \\
\hline MG & $30.0 \pm 2.5$ & $44.7 \pm 12.7$ & $3.3 \pm 0.8$ & $28.0 \pm 10.9$ \\
\hline \multicolumn{5}{|l|}{ Matador } \\
\hline NG & $200.9 \pm 30.8$ & $54.3 \pm 3.5^{*}$ & $101.3 \pm 31.4$ & $139.4 \pm 20.6$ \\
\hline LG & $167.3 \pm 17.0$ & $31.9 \pm 4.6$ & $66.3 \pm 6.7$ & $102.4 \pm 18.6$ \\
\hline \multicolumn{5}{|l|}{ Glenavon } \\
\hline NG & $233.8 \pm 12.8^{*}$ & $25.9 \pm 9.0$ & $121.9 \pm 37.7 *$ & $612.9 \pm 78.6^{*}$ \\
\hline MG & $192.9 \pm 13.9$ & $42.7 \pm 4.4$ & $37.1 \pm 5.1$ & $206.9 \pm 35.2$ \\
\hline HG & $124.1 \pm 27.0$ & $49.5 \pm 13.3$ & $32.0 \pm 16.0$ & $113.4 \pm 65.2$ \\
\hline \multicolumn{5}{|l|}{ Estevan } \\
\hline NG & $151.2 \pm 5.6$ & $22.0 \pm 12.3$ & $92.1 \pm 8.4^{*}$ & $254.1 \pm 34.4$ \\
\hline LG & $144.0 \pm 7.3$ & $23.2 \pm 4.2$ & & $52.0 \pm 7.3$ \\
\hline \multicolumn{5}{|l|}{$219.6 \pm 33.0$} \\
\hline \multicolumn{5}{|l|}{ Parkbeg } \\
\hline NG & $51.8 \pm 4.6$ & $8.8 \pm 2.8$ & $45.8 \pm 5.7$ & $104.6 \pm 14.1 *$ \\
\hline HG & $42.9 \pm 3.3$ & $10.8 \pm 4.5$ & $34.0 \pm 8.2$ & $27.4 \pm 3.1$ \\
\hline \multicolumn{5}{|l|}{ Arena } \\
\hline NG & $55.6 \pm 3.3$ & $37.9 \pm 6.4$ & $11.8 \pm 0.9^{*}$ & $30.8 \pm 1.9$ \\
\hline MG & $61.5 \pm 4.6$ & $32.2 \pm 8.0$ & $7.4 \pm 0.7$ & $31.7 \pm 4.5$ \\
\hline Chaplin & NG & $111.4 \pm 10.3^{*}$ & $25.7 \pm 7.3$ & $30.5 \pm 4.9 *$ \\
\hline \multicolumn{5}{|l|}{$94.4 \pm 25.6^{*}$} \\
\hline $\mathrm{HG}$ & $28.6 \pm 8.5$ & $30.5 \pm 6.4$ & $5.5 \pm 1.0$ & $25.3 \pm 5.6$ \\
\hline \multicolumn{5}{|l|}{ Kerr } \\
\hline NG & $99.6 \pm 13.6^{*}$ & $37.1 \pm 4.3^{*}$ & $29.7 \pm 8.0$ & $110.0 \pm 18.3 *$ \\
\hline HG & $38.0 \pm 3.1$ & $50.7 \pm 1.9$ & $5.4 \pm 2.4$ & $11.9 \pm 2.2$ \\
\hline
\end{tabular}

${ }^{\mathrm{NG}}$ : no grazing, LG: light grazing, MG: moderate grazing, HG: heavy grazing.

${ }^{*}$ indicates a significant difference between ungrazed and grazed sub-sites $(\mathrm{P} \leq 0.05)$. 
Table 4. Structural characteristics of 8 grassland sites in southern Saskatchewan. Values are mean \pm SE of 4 replicates.

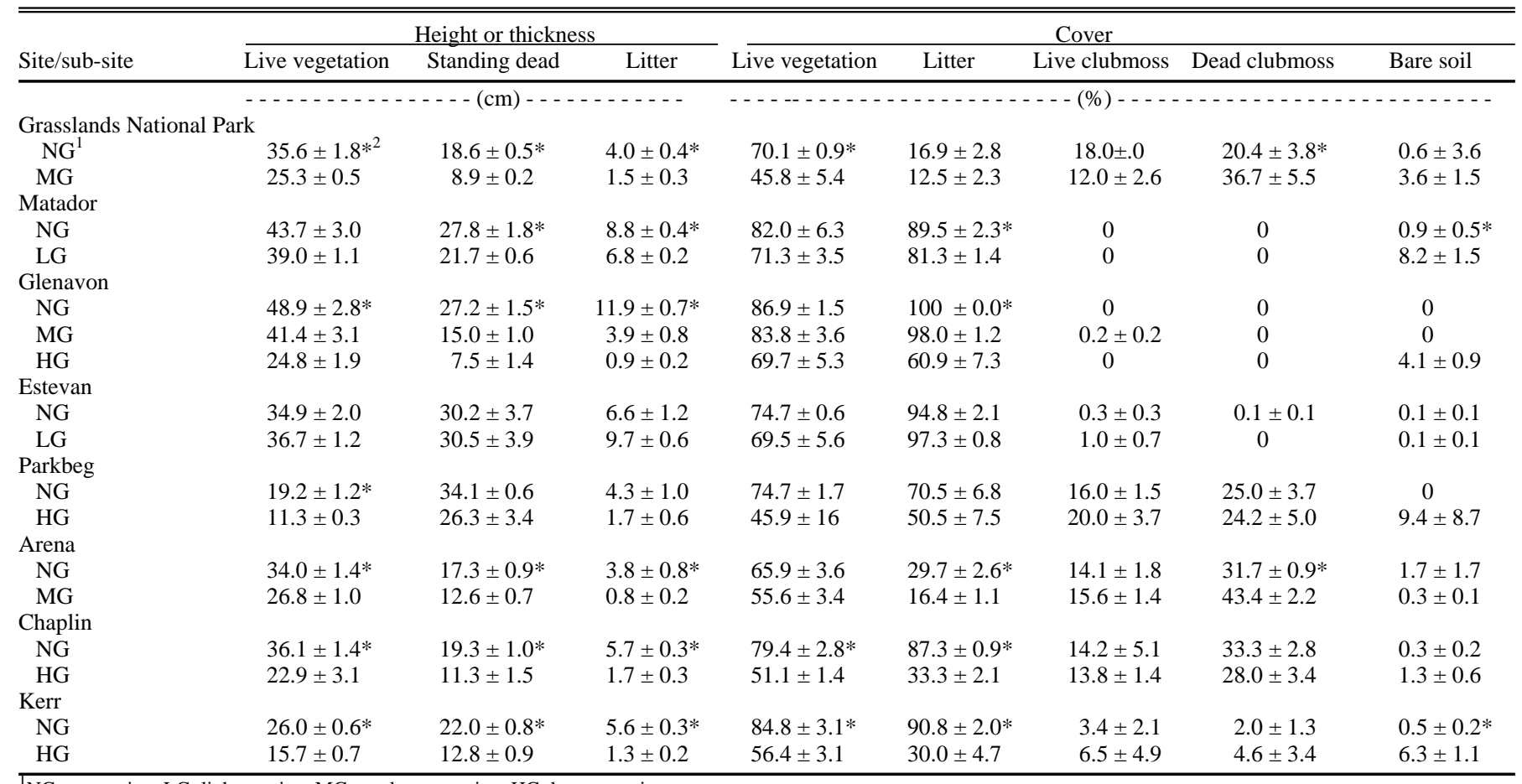

${ }_{2}$ NG: no grazing, LG: light grazing, MG: moderate grazing, HG: heavy grazing.

$2_{*}$ indicates a significant difference between ungrazed and grazed sub-sites $(\mathrm{P} \leq 0.05)$.

Shannon's diversity index $(\mathrm{Y}=-14.8+2$ $\left.6.0 X, P<0.001, r^{2}=0.26\right)$, but that of others such as grass, standing dead material, litter or their combination had weak or no correlation with this index (data not shown). Therefore, results from the current study did not provide evidence that there is a relationship between species diversity and ecosystem stability (measured as biomass) as suggested by Tilman and Downing (1994).

Grazing altered the structure of grassland vegetation. Live vegetation height was reduced both by moderate and heavy grazing, but not by light grazing (Table 4). Total vegetation cover also were reduced by grazing in 3 out of 8 sites, such as GNP (moderate), Chaplin (heavy) and Kerr (heavy). Grazing reduced the height of standing dead materials in all sites except Estevan and Parkbeg. Litter cover and accumulation, measured by its thickness, were also reduced by grazing, similar to previous reports (Schulz and Leininger 1990). Clubmoss cover was site dependent, but grazing tended to increase the cover of dead clubmoss in at least 2 moderately grazed sites (GNP and Arena). Bare soil surface also tended to increase with grazing. The total cover of live vegetation, the cover of litter, the height of live vegetation and standing dead materials, and the thickness of litter increased with range condition following linear or quadratic equations (data not shown).

\section{Canonical Correspondence Analysis}

The CCA joint plot demonstrated the correlation between species composition and parameters such as cover, height, and biomass by the direction and length of lines radiating from the centroid of the ordination scores (Fig. 3). The CCA shows the main pattern of variation in species composition as accounted for by environmental variables and the plot distribution along each variable in an approximate way (Ter Braak 1986). Sites and sub-sites were separated best by Axes 1 and 2, but not Axis 3, in the CCA. Thus, only scores of Axes 1 and 2 are presented here. Among the variables, the cover of live and dead clubmoss and the cover of bare soil were negatively correlated with the cover, height and biomass of other plant materials. Range condition tended to correlate with those parameters, but the angle between them indicates that some parameters did not reach their maximum in excellent condition, and some relationships were not linear.

\section{Conclusion}

Grazing intensity affects plant species diversity, but not species richness, of grasslands in southern Saskatchewan. As the intensity of grazing increases, species diversity tends first to increase and then decrease, but this trend is site-specific. Grazing alters plant species composition, reduces the biomass of grasses and enhances that of forbs. The biomass of standing dead materials and litter is reduced by grazing. Our research results are relevant to the management of grasslands for purposes of protecting plant species diversity, enhancing habitat quality and improving economic returns. Grazing might be appropriate in the management of some wildlife habitats. The diversity of other ecosystem components such as insects, rodents and birds also need to be considered. The challenge remains for wildlife biologists to interpret plant diversity characteristics in relation to wildlife needs for food and cover. Maintaining species diversity should be an important objective of grazing management.

\section{Literature Cited}

Abouguendia, Z.M. 1990. A practical guide to planning for management and improvement of Saskatchewan rangeland. New Pasture and Grazing Techn. Proj., Regina, SK, Canada.

Anderson, V.J. and D.D. Briske. 1995. Herbivore-induced species replacement in grasslands: Is it driven by herbivory tolerance or avoidance? Ecol. Appl. 5:1014-1024.

Archer, S. and F.E. Smeins. 1991. Ecosystems-level processes, p. 109-140. In: R.K. Heitschmidt and J.W. Stuth (eds.), 
Grazing management: An ecological perspective. Timber Press, Portland, Ore.

Brady, W.W., M.R. Stromberg, E.F. Aldon, C.D. Bonham, and S.H. Henry. 1989. Response of a semidesert grassland to 16 years of rest from grazing. J. Range Manage. 42:284-288.

Collins, S.L. 1987. Interaction of disturbances in tallgrass prairie: A field experiment. Ecol. 68:1243-1250.

Cooperrider, A. 1991. Conservation of biodiversity on western rangelands, p. 40-53. In: Integrated bush management systems for South Texas: Development and implementation. Texas Agc. Exp. Sta., Texas A \& M Univ., College Station, B-1493.

Crumpacker, D.W. 1984. Regional riparian research and a multi-university approach to the special problem of livestock grazing in the Rocky Mountains and Great Plains, $p$ 413-422. In: R.E. Warner and K. Hendrix (eds.), California riparian systems: Ecology, conservation, and productive management. Univ. of California Press, Berkeley, Calif.

Davidson, D.W. 1993. The effect of herbivory and granivory on terrestrial plant succession. Oikos 68:23-35.

Fleischner, T.L. 1994. Ecological costs of herbivory grazing in Western North America. Conserv. Biol. 8:629-644.

Hartnett, D.C., K.R. Hickman, and L.E.F. Walter. 1996. Effects of bison grazing, and topography on floristic diversity in tallgrass prairie. J. Range Manage. 49:413-420.

Howitt, R.E. 1995. How economic incentives for growers can benefit diversity. California Agr. 49 (6):28-33.

Huntly, N. 1991. Herbivores and the dynamics of communities and ecosystems. Annu. Rev. Ecol. Systematics 22:477-503.

Kelt, D.A. and T.J. Valone. 1995. Effects of grazing on the abundance and diversity of annual plants in Chihuahua desert habitat Oecologia (Springer-Verlag) 103:191-195.
Longhurst, W.M., R.E. Hafenfeld, and G.E. Connolly. 1982. Deer-livestock relations in the western states, p. 409-420. In: L. Nelson, J.M. Peek, and P.D. Dalke (eds.), Proc. wildlife-livestock relations symposium. Forest, Wildlife and Range Exp. Sta., Univ. of Idaho, Moscow, Ida.

McCune, B. and M.J. Mefford. 1995. PCORD. Multivariate analysis of ecological data, Version 2.0. MjM Software Design. Golden Beach, Ore.

McNaughton, S.J. 1985. Ecology of a grazed system: The Serengeti. Ecol. Monogr. 55:259-294.

Milchunas, D.G., O.E. Sala, and W.L. Lauenroth. 1988. A generalized model of the effects of grazing by large herbivores on grassland community structure. Amer. Natur. 132:87-105.

Olff, H. and M.E. Ritchie. 1998. Effects of herbivores on grassland plant diversity. Trends Ecol. Evol. 13:261-265.

Padbury, G.A. and D.F. Acton. 1994. Ecoregions of Saskatchewan. Centre for Land and Biol. Resources Res., Res. Branch, Agr. and Agri-Food Canada. Ottawa, Ontario, Canada.

Ritchie, M.E. and H. Olff. 1998. Herbivore diversity and plant dynamics: Compensatory and additive effects, p. 175-203. In: H. Olff, V.K. Brown, and R.H. Drent (eds.), Herbivores between plants and predators. Blackwell Sci., Oxford.

Savory, A. 1988. Holistic resource management. Island Press, Covelo, Calif.

Schulz, T.T. and W.C. Leininger. 1990. Differences in riparian vegetation structure between grazed areas and exclosures. J. Range Manage. 43:295-299.

Smart, N.O.E., J.C. Hatton, and D.H.N. Spence. 1985. The effect of long-term exclusion of large herbivores on vegetation in Murchison Falls National Park, Uganda. Biol. Conserv. 33:229-245.
Smith, G., J.L. Holechek, and M. Cardenas. 1996. Wildlife numbers on excellent and good condition Chihuahuan desert rangelands: An observation. J. Range Manage. 49:489-493.

Snedecor, G.W. and W.C. Cochran. 1980. Statistical methods ( $7^{\text {th }}$ ed.). Iowa State Univ. Press. Ames, Iowa.

Sousa, W.P. 1980. The responses of a community to disturbance: The importance of successional age and species life histories. Oecologia (Berl.) 45:72-81.

Stelljes, K.B. and D. Senft. 1994. Sciences at home on the range. Agr. Res. 1994 (Nov.):4-8.

Szaro, R.C. 1989. Riparian forest and scrubland community types of Arizona and New Mexico. Desert Plant 9:69-138.

Ten Harkel, M.J. and F. Van der Meulen. 1996. Impact of grazing and atmospheric nitrogen deposition on the vegetation of dry coastal dune grasslands. J. Vegetation Sci. $7: 445-452$.

Ter Braak, C.J.F. 1986. Canonical correspondence analysis: A new eigenvector technique for multivariate direct gradient analysis. Ecol. 67:1167-1179.

Tilman, D. and J.A. Downing. 1994. Biodiversity and stability in grasslands. Nature 367:363-365.

Wagner, F.H. 1978. Livestock grazing and the livestock industry, p. 121-145. In: H.P. Brokaw (ed.), Wildlife and America. Council on Environ. Quality, Washington, DC.

Watt, T.A., J.R. Treweek, and F.S. Woolmer. 1996. An experimental study of the impact of seasonal sheep grazing on formerly fertilized grassland. J. Vegetation Sci. 7:535-542.

West, N.E. 1993. Biodiversity of rangelands. J. Range Manage. 46:2-13. 